\title{
QUEEN'S
UNIVERSITY
BELFAST
}

\section{Deliberative Democracy in Northern Ireland: Opportunities and challenges for consensus in a consociational system}

Hayward, K. (2014). Deliberative Democracy in Northern Ireland: Opportunities and challenges for consensus in a consociational system. In J. Ugarizza, \& D. Caluwaerts (Eds.), Democratic Deliberation in Deeply Divided Societies: From Conflict to Common Ground (pp. 11-34). Palgrave Macmillan.

http://www.palgrave.com/page/detail/democratic-deliberation-in-deeply-divided-societies-juanugarriza/?K=9781137357809

Published in:

Democratic Deliberation in Deeply Divided Societies: From Conflict to Common Ground

Document Version:

Early version, also known as pre-print

Queen's University Belfast - Research Portal:

Link to publication record in Queen's University Belfast Research Portal

\section{Publisher rights}

Copyright 2014 Hayward

Ugarriza, E., Caluwaerts, D. (Eds.), Democratic Deliberation in Deeply Divided Societies: From Conflict to Common Ground, 2014, Published by Palgrave Macmillan reproduced with permission of Palgrave Macmillan.

This extract is taken from the author's original manuscript and has not been edited. The definitive, published, version of record is available here: http://www.palgrave.com/gb/book/9781137357809

\section{General rights}

Copyright for the publications made accessible via the Queen's University Belfast Research Portal is retained by the author(s) and / or other copyright owners and it is a condition of accessing these publications that users recognise and abide by the legal requirements associated with these rights.

\section{Take down policy}

The Research Portal is Queen's institutional repository that provides access to Queen's research output. Every effort has been made to ensure that content in the Research Portal does not infringe any person's rights, or applicable UK laws. If you discover content in the Research Portal that you believe breaches copyright or violates any law, please contact openaccess@qub.ac.uk. 


\section{Author's preprint version, July 2014.}

in Juan Ugarriza and Didier Caluwaerts (eds) Democratic Deliberation in Deeply Divided Societies: From Conflict to Common Ground, London: Palgrave Macmillan, pp.11-34. 


\section{Part I}

\section{Obstacles and Opportunities for Deliberation in Divided Societies}




\title{
Deliberative Democracy in Northern Ireland: Opportunities and Challenges for Consensus in a Consociational System
}

\author{
Katy Hayward \\ in Juan Ugarriza and Didier Caluwaerts (eds) Democratic Deliberation in Deeply Divided \\ Societies: From Conflict to Common Ground, London: Palgrave Macmillan, pp.11-34.
}

\begin{abstract}
The 1998 Multiparty Agreement established a consociational system that contains within it an explicit dualism: unionist/nationalist, north and south of Ireland, and British and Irish. But although this formula has facilitated relatively stable and devolved governance, it is based on a distorted representation of a society in which there are much more complex divisions and, indeed, many common problems. Citizenled efforts towards deliberative democracy since the 1980s have demonstrated both the will and the capacity for alternative, consensual political expressions. This chapter examines the challenges and opportunities facing these citizen-led initiatives in a political environment which, despite the significant decline in violence and terror, seems stubbornly resistant to the idea of broadening the various means of democratic participation.
\end{abstract}

The Good Friday (Belfast) Agreement of April 1998 is, in essence, a consociational arrangement which sees power shared between elites from two political blocs in Northern Ireland: unionism and nationalism. ${ }^{1}$ When parties signed the Agreement, in effect they agreed to accept the prospect of two divergent aspirations: Northern Ireland could remain in the United Kingdom, which was what unionist parties wanted, or it could be integrated into a single Republic of Ireland, as sought by nationalist parties. As a consequence, although benefitting from the devolved, stable and carefully balanced governance made possible by consociationalism, Northern Ireland's peace process is imbued with a sense of underlying lack of resolution. And as a result of this uncertainty, short-term political capital is gained within competing blocs at the expense of long-term social change in the common interest. 
Indeed, it is increasingly difficult to express shared goals and interests clearly in a political environment where finding a 'majority' (albeit weighted or parallel [see NIA, 2010]) takes precedence over the need to build 'consensus'. This is because the 1998 Agreement takes it for granted that the conflict in Northern Ireland is one of binaries: unionist versus nationalist, Catholic versus Protestant, British versus Irish. Not only that, it presents an even more reductive, simplified analysis of Northern Ireland society, one in which these binaries combine to produce a single gaping divide: unionist/Protestant/British versus nationalist/Catholic/Irish. In this context, the slim but nascent capacity for deliberative democracy that was embedded in the 1998 Agreement (as discussed later) remains unrealized due to resistance from most political parties, which are conditioned to placing priority on consolidating the power they have within the blocs rather than on making efforts to find consensus across them. Most efforts at deliberative democracy in Northern Ireland - facilitating constructive discussion and searching for the common good - are therefore still, largely, the product of citizen-led initiatives.

\section{POLITICAL STALEMATE OVER 'WICKED’ PROBLEMS}

Notwithstanding the importance of considerations other than democracy in the early stages of peacebuilding (Collier et al., 2008; Zürcher, 2011), Northern Ireland has now reached a point where the very functioning of its democracy is increasingly being obstructed by 'wicked' problems. The relative stability that was achieved as a result of the 1998 Agreement and the supplementary 2006 St. Andrews Agreement ${ }^{2}$ is threatened by two related challenges: voter apathy and extremism (including paramilitary groups). The risk of extremism is exacerbated by the increase in voter disaffection ${ }^{3}$ which, in turn, is worsened by the persistence of 'wicked' problems that regularly result in street violence. ${ }^{4}$ These problems are recurring issues characterized by divergent public values and sensitivities, and they are so imbued with complex risks and uncertainties that they seem intractable, while traditional policy efforts tend to result in stalemate (Balint et al., 2011; Rittel \& Webber, 1973).

In Northern Ireland, problems like these are often associated with a clash between cultural and civil rights, such as unionist Orange Parades through nationalist areas. Whereas consociationalism mechanisms are ill-suited to resolving these 'wicked' problems, deliberative democratic practices may be a viable way of addressing them because of their flexibility, the fact that they can include those directly 
affected and their potential for enabling value change and consensus (Fishkin and Luskin, 2005; Fung, 2003; Janeczko, 2011). The capacity for deliberative practice already exists in Northern Ireland and, as this chapter will show, it has been proven by several citizen-led initiatives and experiments since the 1980 s. The biggest obstacle to any expansion of these practices lies in the reluctance of power-holders in a consociational system pinned upon communal division.

\section{THE FALSE BINARY}

Any analysis of the nature of the conflict in Northern Ireland needs to distinguish between the complex multitude of differences that exist and the simplified but dominant interpretation of the conflict as being between two all-encompassing communities. A typical 'explanation' of the conflict in Northern Ireland starts, somewhere between the twelfth and twentieth centuries, with warring between Britain and Ireland as territorial neighbors, and ends in micro-level antagonism between Protestant and Catholic next-door neighbors. The drawing of such a thread through history is speciously validated in contemporary Northern Ireland by the close connections between British and Protestantism, on the one hand, and Irish and Catholicism, on the other. However, the tightness of such identity connections and connotations is due in no small part to the effects of the recent conflict. As Figure 2.1 shows, the beginning of the Troubles in the late 1960s had an immediate, deleterious effect on the willingness of Protestants to self-identify as 'Irish'. The religious schism between Irish and British identifications since that point is clearly apparent.

Figure 2.1<em \#>Percentage of Catholic and Protestant respondents self-identifying as 'British' or 'Irish'.5

On closer analysis, however, we can see that this impression of polarization is not validated in the form of a predominance of Catholics identifying as Irish and/or nationalist, or Protestants as British and/or unionist. Indeed, according to Northern Ireland Life and Times Survey (NILT, 2010), ${ }^{6}$ only 61 percent of Protestants identify as British and 65 percent as unionist, and only 54 percent of Catholics identify as Irish and 51 percent as nationalist. Therefore, what gives the impression of community polarization within Northern Ireland is, in fact, the rarity of Catholics who identify as British ( 8 percent) or unionist (1 percent), and of Protestants who identify as Irish ( 4 percent) or nationalist (less than 0.5 percent). For the sake of simplicity, the post-Agreement political system is based on a clear division between nationalists 
(who are almost wholly Catholic) and unionists (who are almost wholly Protestant). But this almost willfully ignores the fact that 35 percent of Protestants and 45 percent of Catholics have no wish to describe themselves as either nationalist or unionist. ${ }^{7}$ Why is it, then, that the political system in Northern Ireland is designed to underpin a political divide that almost half the population, across all religious affiliations, rejects? ${ }^{8}$

\section{Other significant divisions}

Although it is embedded in institutional power, the nationalist/unionist political divide should not be automatically thought of as crossing into other forms of social and economic division. The historical ramifications of discrimination against Catholics in Northern Ireland are slowly being overcome by Fair Employment legislation (Muttarak et al., 2013). Although unemployment rates are still higher for Catholics ( 9 percent) than for Protestants ( 6 percent), there has been a rapid catch-up in economic activity, largely the result of educational achievement (Nolan, 2013). More striking are the opportunity gaps that cut across religious or political communities: 43 percent of children in West Belfast live in poverty, the difference in life expectancy between the least and most deprived areas in Belfast is almost 12 years and 29 percent of adults have no educational qualifications at all (Nolan, 2013; Padley and Hirsch, 2013).

As the Catholic middle class grows, its luxury lies in it having access to more mixed employment

and residential areas (residential segregation is severest in the most materially deprived areas) (Gaffikin and Morrissey, 2011, p. 22). But educational segregation remains the norm: only 7 percent of schools in Northern Ireland are integrated schools with a balanced intake policy for Catholic and Protestant pupils (Nolan, 2013). This persistent segregation has the effect of producing generation after generation who, while not immune to the effects of secularization, are only too aware of their 'perceived religious affiliation'. Although, as noted earlier, this does not determine their political opinions, or nowadays their employment prospects, it still, in effect, imposes restrictions on their political and life choices.

\section{THE RAMIFICATIONS OF CONSOCIATIONALISM}

All signatories to the 1998 Agreement endorsed, in their 'Declaration of Support', a commitment to 'partnership, equality and mutual respect', as well as to 'exclusively democratic and peaceful means of resolving differences'. But these principles were seen to underpin the 'identity, ethos, and aspirations of 
both communities' (i.e., unionist and nationalist), rather than to cast doubt on them or create an alternative. ${ }^{9}$ The premise in the peace process is thus based on creating a balance between two communities and giving equal weight to the political aspirations held by a minority of them. The concept of equality which 'structures almost every aspect of the Agreement' (and the 1998 Northern Ireland Act implementing it) is therefore one that institutionalizes a 'two communities' model of governance (Harvey, 2000, p. 84, 90). Little (2008, p. 13) notes that peace agreements tread a fine line between reflecting political divisions and materializing them; critics of consociationalism argue that the Agreement made this very mistake (Hayes and McAllister, 2013). The consociational model adopted in the Agreement viewed the inclusion of all parties as critical, yet it gave them a choice of only two designations, nationalist or unionist, so that significant power could be held within the Assembly, such as when the requirement for cross-community consent stipulates a qualified or super-majority in voting on certain policy issues, as with the Portfolio of Ministers (NIA, 2010). This reflects the principle of deference to group solidarity and elite leadership that is so central to consociationalism (Sisk, 1996, p. 47).

The consociational mechanisms embodied in post-Agreement Northern Ireland have been hugely successful in translating the 'parity of esteem' stated in the text of the Agreement into real political power, but only insofar as that parity is between two poles, namely, unionist and nationalist. Porter (2000a, p. 149, 142) argues that broadening out 'recognition' to groups that do not fit within the 'two communities' is particularly difficult, not just because of the consociational arrangements but also because the experience of conflict in Northern Ireland has made the very notion of distinctiveness problematic. Her analysis is set within the context of the quest for gender equality in Northern Ireland, specifically with regard to the experience of the Northern Ireland Women's Coalition (NIWC) in the political sphere. This party was inclusive in its class, community and regional membership; it was also inclusive in the goals it brought to the multiparty negotiations which led to the Agreement (Porter, 2000a, p. 145).${ }^{10}$ It no doubt played a part in getting an emphasis on human rights, integration and equality incorporated into the final Agreement, but its fate, at the sharp end of the unionist/nationalist requirement of full political effect in the Assembly, is emblematic of the hostile environment for an identity/affiliation 'other' than unionist or nationalist - even that of woman! 


\section{Obstacles to political inclusion and equality}

Institutional and civic obstacles to democratic inclusion and political equality in Northern Ireland thus work symbiotically. Political divisions are simplified into one binary, which then becomes the principal powersharing line; parties thereafter compete for votes on one side or the other of this binary, claiming in the process to best represent their side's interests, which are all too easily defined as being contrary to those of the other side. ${ }^{11}$ Success in building up strength of force on one side or the other is rewarded at the institutional level. There is political resistance, therefore, to any perceived dilution of this apportioning of power. At the elite level, agreement across the divide on policy matters is a product of careful bargaining and consideration, as there is little incentive for leadership to be in a cross-community direction. Indeed, political leaders can gain by maintaining deep divisions (Steiner, 2012, p. 14). Moreover, there is little pressure for any changes to be made in this pattern, given the prevalence of segregation in Northern Ireland society $^{12}$ and the failure of parties representing 'other' perspectives to represent much of a challenge to this convenient set up. ${ }^{13}$ Responsibility for both regression and progression in terms of integration is thus seen as residing largely at citizen level: on the one hand, on the shoulders of those who come to the fore in 'defense' of community interests; on the other, with those who persist in efforts aimed at cross-community development and engagement, despite working on the basis of short-term grants rather than the promise of long-term policy change. Meanwhile, among the 'silent majority', apathy grows, along with suspicion of politicians' motives and a weariness at the lack of progress in tackling persistent, not to mention 'wicked', economic and social problems (Steiner, 2012, p. 26). ${ }^{14}$

\section{The alternative of deliberative democracy}

Voting in divided societies runs the risk of further alienation and antagonism, as a consociational system can further encourage the strong expression of 'mutually contradictory assertions of identity' between the groups concerned (Dryzek, 2005, p. 219). An alternative to pinning the power to make decisions to the totem pole of 'community' is for preferences to be expressed in a non-adversarial way. Various deliberative democracy mechanisms have the potential to bring to light preferences that do not fit into the dominant modes, and give them political weight, the intention being that solidarity will be created through the shared political process, as an alternative to being constructed outside the Assembly and then used to hinder progress within it. 
O’Flynn (2007) argues that the moderation (as sought by Horowitz's [1993] incentives-based model of democracy) and inclusion (as sought by Lijphart's [1969] consociational model of democracy) requirements are actually both met if political equality, as conceived by deliberative democracy, is upheld. Such a deliberative conception of equality differs from that stated in the Agreement in that it rewards parties on the basis not merely of their stated preferences but rather of their ability to give reasons for their preference and to adapt them. Preferences are therefore not fixed, nor are they determined by designation; instead, they are responsive to the views of others (Miller, 1993, p. 75). One core assumption of deliberative democracy, therefore, is that participants have the 'capacity to be swayed', be it by rational arguments or by appeals to commonality (Miller, 2003, p. 183). As a consequence, deliberative democracy requires 'reason-giving' by all participants, as opposed to mere appeals to identity or interests (Gutmann and Thompson, 2004, p. 3). To pick up on a point made by Porter (2000a, p. 160), politics requires both speaking and listening. The Northern Ireland Assembly has become a vital arena for speaking, but the mechanisms of democracy within it (like most parliaments) do not create the necessary conditions for listening or, indeed, for changing as a result.

\section{INSTITUTIONAL MECHANISMS FOR DELIBERATIVE DEMOCRACY}

The fact that the Agreement is not a purely consociational model, but rather contains within it opportunities for deliberation at various levels should not be overlooked. Each of the three 'strands' of the Agreement (unionist/nationalist within Northern Ireland, north/south on the island of Ireland and British/Irish across the islands known as the British Isles) has provided opportunities for deliberation. Deliberative principles have been implemented most successfully at institutions where government representatives have been involved (e.g., British/Irish, North/South) and least so at those where representative samples of citizens have been directly involved (e.g., North/South Consultative Forum or the Northern Ireland Civic Forum).

\section{Finding consensus among government representatives}

The British-Irish Council (BIC) was established in 1999 so that representatives of the British government, the Irish government, the regional governments of the United Kingdom (including the Northern Ireland Executive) and the governments of the three British Crown Dependencies (e.g., the government of the bailiwick of Jersey) could 'exchange information, discuss, consult and use best endeavors to reach 
agreement on cooperation on matters of mutual interest', as set out in Strand Three of the 1998 Agreement. Common policies and actions 'in areas of mutual interest' can arise from the work of the BIC, which 'normally operates by consensus' (BIC, 2013). These areas have expanded since the BIC was formed, and nowadays include cooperative spatial planning, digital inclusion, environment, and energy. The deliberative logic behind the BIC is evident, in that its primary emphasis is on exchanging views as a means of promoting 'positive, practical relationships' (BIC, 2013).

As far as Strand Two is concerned, the North/South Ministerial Council (NSMC) was formed with a similar remit, namely, to facilitate consultation and cooperation between the Irish government and the Northern Ireland Executive on matters of mutual interest, but in this case there was far greater potential for controversy. Because it established a formal institutional channel for high-level cooperation between the Republic of Ireland and Northern Ireland, the NSMC was vitally important if nationalist support was to be obtained for the Agreement, yet at the same time, it was something that was difficult for unionists to accept. The Council meets in plenary session twice yearly, with more regular sector meetings being held between ministers responsible for each of the 12 common policy areas covered by the NSMC. These sector meetings always include three ministers: the Irish minister or minister of state responsible for the area, and two ministers from the Northern Ireland Executive, nominated by the first and deputy first ministers on a crosscommunity basis; this condition was established as a way to mitigate unionist unease. However, on the whole, the NSMC is a low-key operation and is much more likely to attract photo opportunities than controversy. Despite this, sensitivities still remain too high for progress to be made on establishing what is potentially the most advanced deliberative democracy body on the island of Ireland, the North/South Consultative Forum.

\section{Political reticence towards civil society representation}

A consultative forum between the two jurisdictions on the island was envisaged, though not promised, in the Agreement (Strand Two, Art. 19), and just prior to its suspension in 2002, ${ }^{15}$ a plenary session of the NSMC agreed on an outline structure for such a forum: '[A] twice yearly conference will take place, alternating between north and south, comprising representatives of civil society, north and south' (NSMC, 2002). Since the restoration of devolution in 2007, and with it the NSMC, the North/South Consultative 
Forum has been on the agenda of every plenary session of the NSMC. In June 2011, the NSMC plenary session communiqué promised that plans for the forum would be finalized at the following plenary session (NSMC, 2011, Art. 11). This promise was repeated at every plenary session from that point until November 2012, since when a new formula has appeared on the agenda under the North/South Consultative Forum heading, and prospects for it are even more uncertain, in that the agreement is merely 'to review this issue at a future NSMC Plenary' (NSMC, 2012, Art. 10; NSMC, 2013, Art. 17). The fact that it is persistently on the table is a reflection of the input by the Irish government and ministers from northern nationalist parties, ${ }^{16}$ while the fact that no progress is made reflects the resistance of unionist parties and the veto effect of the power-sharing conditions embodied in the NSMC.

\section{The Civic Forum}

The same debates and stalling are evident in the Northern Ireland Civic Forum, the consultative body designed for deliberation within Northern Ireland. One particularly pertinent remark about this initiative was that 'the Civic Forum should be about problem-solving and alternative thinking ... and, boy, do we need alternative thinking in Northern Ireland' (Morrice, 2001). The 1998 Agreement (Strand One, Art. 34) envisaged that the forum would be 'a consultative mechanism on social, economic and cultural issues'. It would be a potential channel of communication between government and civil society, and a way to allow group interests otherwise overlooked in the consociational system to participate in the political system (O’Flynn, 2006, p. 146). In October 2000, 60 people from a range of sectors including trade unions, agriculture, churches, sport and education were appointed to the forum, and it met a total of 12 times over the ensuing two years, before the suspension of the Assembly. Since that point, as with the North South Consultative Forum, the Northern Ireland Civic Forum has been little more than a political football between unionism and nationalism.

In February 2001, the Assembly had agreed that the forum would 'offer its views on such social, economic and cultural matters as are from time to time agreed between the Chairperson of the Forum and the First Minister and Deputy First Minister' (Trimble, 2001). This was presented at the time by the first minister, David Trimble (2001), as a mechanism that would provide 'for dialogue and for an agreed agenda to which the Executive, the Forum and the Assembly can work in a coordinated way'. In addition, the requirement that the Assembly pass a motion in order to hear the views expressed by the forum on specific 
social, economic and cultural matters was presented by Trimble as a way to avoid overloading it, rather than to restrict its likely influence on political decision-making. Even so, there was heated debate in the Assembly about the purpose and function of the forum's deliberations, and the hardline Democratic Unionist Party (DUP) took advantage of the situation to pile further pressure on the then first minister, David Trimble, and his moderate Ulster Unionist Party (UUP). Given this background, it is disappointing that since devolution was restored in 2007, the UUP has shifted closer to the position of the DUP and become overtly opposed to the revival of the Civic Forum. It was not until April 2013 that a motion to reconvene the Forum was put forward by the moderate nationalist party, the SDLP. With support from the hardline nationalist party Sinn Féin and other parties such as the centrist Alliance and the Green Party, the motion was passed, but only just - by 48 votes to $47 .{ }^{17}$ The very notion of a participative Civic Forum has thus, ironically, become a subject on which unionist and nationalist parties are directly opposed.

\section{EXPERIMENTS IN DELIBERATION}

Beyond the reach of constitutional structures, a wide range of civic organizations help foster opportunities for deliberation. Ground-breaking experiments in deliberative democracy in Northern Ireland were conducted during the Troubles by the New Ireland Group. The Group was a small collection of individuals who set out to look for alternative ways of approaching politics in Northern Ireland, because 'they were at a loss to know what to do' when faced with the violent conflict and the erosion of democratic norms. ${ }^{18}$ One of these individuals, Peter Emerson, suggested in a letter to the Irish Times in 1977 that the multi-option vote might be beneficial in a divided society such as Northern Ireland. His reasons for advocating this form of voting were that allowing people to say 'yes' to options, even the least favored, in order of preference and without saying 'no' to anything had the advantage that it minimized the risk of discussion being blocked and further conflict provoked by voting. ${ }^{19}$ The logic behind Emerson's (2010) analysis was very much in line with that expressed in other conceptualizations of deliberative democracy. 'If there is some common ground', he argues, 'then the process should be able to identify it, and with a fair degree of precision' (p. 83).

In 1986, under the auspices of the New Ireland Group, Emerson had an opportunity to experiment with this deliberation method. The New Ireland Group organized three events during the year at a neutral 
venue, Queen's University Students' Union. All known political associations in Northern Ireland were invited to, and participated in, these deliberative conventions, an achievement that required a certain amount of negotiation even prior to the event itself. ${ }^{20}$ And a great deal of management was needed to make the events a success. Journalists were invited to chair the different sessions, with a view to generating media awareness, and the personal networks of New Ireland Group members were utilized to ensure that as many people as possible were involved in a variety of ways, ranging from leading the crèche to taking minutes of proceedings. An average of 200 people participated in each of the three conventions. Further conventions organized by the Group in the early 1990s saw progress made with the methods, as mechanisms for presenting proposals became computerized. Participation in the conventions also broadened, as parties from the Republic of Ireland attended.

The level of sophistication achieved in these forums is worth noting. Explicit instructions for the proceedings were agreed on and sent to the chairs of the sessions well in advance. The seating was in a circular formation, to encourage mixing and avoid any spatial replication of political opposition. Each plenary session began in silence. A representative of each party was then given precisely three minutes to outline the party's views on the subject under discussion. A team of 'consensors' would then turn the respective proposals into a ballot paper. After this, the meeting split into break-out workshops to discuss the proposals, before reconvening in a plenary session at which the ballot paper, comprising an agreed summary of the various proposals, was distributed. The voting on this paper was in order of preference, and analysis a form of Borda count, the purpose being to find a level of consensus, namely, the option that won the most support from across the spectrum. ${ }^{21}$ In line with the norms governing deliberative democracy, Emerson (2010, p. 86) and Robb (1991, p. 1) note that the procedures for consensus voting, such as the outlining of positions, the opportunity to ask questions and the requirement to listen, coupled with the clear structure of the conventions, helped to create an atmosphere that was conducive to consensus before any vote took place.

\section{Experiments in deliberative polling}

In addition to these consultative conventions, the New Ireland Group, with funding from the Joseph Rowntree Foundation, conducted a survey that followed its 'preferendum' model (Emerson, 1998). In this 
case, it first gathered proposals from a range of parties for addressing the constitutional future of Northern Ireland. These proposals were then collated, in summary form, as a selection of options by a small team of independent experts. There were fewer options than parties, as the options proffered reflected the range of alternatives rather than party positions. They were then taken by a market research company and used to survey a random sample of 1,000 voters, whose preferences were recorded by their putting in order a small selection of cards, each of which contained one option. The consensual outcome bore a close resemblance to the outcome of the 1998 Agreement (which was announced just after the survey was conducted), namely, devolved power-sharing at regional level with institutional input from the Republic of Ireland and Britain.

More recently, Fishkin, Luskin, O’Flynn and Russell (see Fishkin, 2009, pp. 161-166; Luskin et al., forthcoming) conducted an experiment to test how useful deliberation was in addressing the particularly controversial issue of education in Northern Ireland. A random sample of Catholic and Protestant participants was selected from a locality in south-west Northern Ireland to discuss local school issues. Each participant completed a questionnaire in advance and was given a briefing document on the various options for providing education, including arguments for and against each one. When the participants met for a day of organized deliberation, they were put into groups of about ten for respectful discussion of the issues, under the supervision of a moderator. Analysis of questionnaires completed by the participants after these discussions showed that the participants then held 'much more positive views of the other community and of intercommunity relations' (Luskin et al., forthcoming).

\section{The citizens' inquiry}

Arguably the greatest resource for deliberative democracy in Northern Ireland, as well as for conflict transformation, is the size and experience of organization within the community and volunteer sector. One attempt in this context to build on the potential for enhancing quality in the democratic contribution to the peace process was the Opsahl Commission. Named after its invited chair, the Opsahl Commission met in the form of a 'citizens' inquiry' in 1992-3, a year before the paramilitary ceasefires at the start of the peace process. It received over 500 written and oral submissions from individuals and groups, and also arranged hearings around the province for the specific purpose of taking on board people's ideas on ways out of the conflict (Pollak, 1993a). The motivation behind this ground-level initiative was to challenge the situation 
where 'the people of Northern Ireland were being reduced to mere spectators of their fate', and it revealed not only the value of communication but also, and more importantly, the need for 'new voices and new words' in political debate (Pollak, 1993b).

Contributions came from a wide range of people and groups, including some that had never taken part in politics previously. Additionally, all political parties responded, with the exception of the DUP, which was also the party that refused to participate in the multiparty negotiations in the contemporary peace process. Typical of the obsessive focus on the constitutional question rather than the range of cultural, economic and social issues addressed by the Opsahl Commission, most media coverage of the initiative focused on the Report's conclusion that public consensus on a political 'solution' to the conflict rested on a formula for joint authority between the British and Irish governments over Northern Ireland. ${ }^{22}$ By daring to outline a proposal which required compromise between all political sides, the Commission ventured into territory that was simply too sensitive, and political support for it, and for such public consultations in the future, rapidly withered away.

\section{Generating new ideas}

The Opsahl Commission has nevertheless left many positive legacies in terms of efforts to broaden political deliberation in Northern Ireland. One worth noting is the forming, in 1995, of Democratic Dialogue, a Belfast-based think-tank. This was established by one of the original founders of Initiative '92, Robin Wilson (1995, p. 1), for the specific purpose of 'generating new ideas' about 'the critical issues confronting people in Northern Ireland'. To that end, Democratic Dialogue became the source of a regular publication and reports, in an attempt to bring fresh thinking and new evidence to political debate in Northern Ireland. Tying in with Gutmann and Thompson's (2004) emphasis on the importance of argument in deliberative democracy, Democratic Dialogue sought to build on the Opsahl Commission's 'willingness to participate in public debate in a way that perhaps had not been evident before in Northern Ireland. And not only to participate - but to be prepared, as at the hearings, to present an argument, explain it and defend it' (Wilson, 1995, p. 1).

Democratic Dialogue worked for over a decade, and Robin Wilson then went on to form Platform for Change which, although not producing written publications, aims to continue facilitating healthy public 
debate in Northern Ireland by organizing forums (half-day or evening events) for open discussion between concerned citizens, either on specific topics that appear to be incapable of being resolved at the political level, such as integrated education or the debate about flags, or in response to current events such as elections. ${ }^{23}$ Although it does make occasional submissions to Assembly committees, the primary intention of Platform for Change is not to have a political effect; instead, it seeks to foster the exchange of ideas about policy matters in Northern Ireland among a diverse group of engaged citizens in a forum uniquely free from party politics.

This goal is made all the easier these days by digital technology, and Platform for Change is one of a growing number of organizations in Northern Ireland that use the Internet and social media (e.g., Facebook, Twitter, LinkedIn, Word Press) to foster debate and comment on current affairs. Indeed, there are notable examples of Internet-based communication being used not just to report or comment on realtime events, but to actually stimulate the establishment of face-to-face contact between individuals. ${ }^{24}$ This new predominance of digital media in open communication between people on important public affairs in Northern Ireland may turn out to be essential, if deliberative initiatives are to be sustained in the short to medium term.

\section{THE MISUSE OF PUBLIC CONSULTATION}

In view of the many positive examples of citizen-led initiatives for public discussion, as well as the relative ease with which ideas and views can be communicated in the digital age, it is regrettable that governmental consultation efforts in Northern Ireland are still so few and so traditional, since they rely in the main on written submissions. The most significant consultative exercise by the Office of the First and Deputy First Ministers since the restoration of devolution has been the one on the draft Cohesion, Sharing and Integration (CSI) program for improving community relations in Northern Ireland. However, progress on this program ironically encapsulates the very obstacles to consensus that are so inherent in a system based on sharing out power between party blocs.

An announcement was made in January 2008 that it was intended to draw up a Cohesion, Sharing and Integration policy, and by autumn there were indications that a draft had been produced. However, the appearance of different versions of this draft on the DUP and Sinn Féin websites in late 2008 and 2009 
gave little cause for confidence, and it was clear that the policy was a bone of contention between the two parties. The draft CSI program was eventually published in July 2010, and a brief consultation exercise on the document was launched. This consultation process was based on a questionnaire and written submissions, of which hundreds were received, from a wide range of civil society bodies ranging from sports associations to universities, religious groups and community centers, as well as from almost 50 individuals (OFMDFM, 2010, 2011). It is fair to say that the CSI program was roundly criticized by civil society organizations for representing a backward step from the goal of reconciliation, to a version of 'mutual accommodation' and 'tolerance' in a society of two communities, with little space for fostering deliberation or consensus (Ruane and Todd, 2010).

The prospects for an agreed policy on the matter seemed very poor until May 2013, when the first minister and deputy first minister announced a new strategy, called Together: Building a United Community (OFMDFM, 2013). While emphasizing equality, the inclusion of surprisingly ambitious goals, including the removal of interface 'peace' walls by 2023, indicates that a primary purpose of the document was to grab headlines - and not just in the local media. ${ }^{25}$ Not only had the goal of sharing and integration become subject to political threats and cynical power games, public consultation on this crucially important matter had been made a pointless exercise. Bickerford (cited Porter, 2000a, p. 157) argues that the critical ingredient for making deliberative democracy a success is attention. Why would people make the effort to speak, to listen, to overcome the fear of sharing ideas and to take the risk of moderation (Mutz, 2006, p. 150; Porter, 2000b), if such processes of consultation, let alone deliberation, remained fruitless and ignored?

\section{THE EFFECTS OF POLITICAL RETICENCE}

Almost 30 years after the first citizen-level efforts at deliberative democracy and 15 years since the consociational model of governance was established in Northern Ireland, what is the status of deliberative democracy in this divided society? At the institution level, the potential for deliberative democracy that was embedded in the 1998 Agreement has been whittled away rather than enhanced. That said, state- and regional-level consultation and consensus-finding between elected representatives from different jurisdictions appear to be the most successful elements of the Agreement that utilize deliberation principles. 
The example and influence of the European Union is arguably significant in the successful work of these supra-state bodies. However, as with the EU, the model falters at civil society level, although in this case it is due less to citizen apathy than to high-level political maneuvering.

The potential for civic deliberation has taken a direct hit from the 'conflict cleavage', as the political parties in charge of putting these forums in place have failed to agree even in principle on whether or not they should be established. Political sensitivities overwhelmed the first, short-lived manifestation of the Northern Ireland Civic Forum, and the fact that the 2013 majority in favor of restoring it was just one and the vote was split down unionist/nationalist lines suggests that any future versions of it will be similarly hamstrung. And the prospects for a North/South Consultative Forum look more distant than ever. So, while debates about civic forums are well-worn and party posturing patterns remain unchanged, public consultations are used as a way of appearing to do something, while delaying the necessary political compromise. Use of the consultation exercise over the Cohesion, Sharing and Integration proposals indicates a lack of political will to find common ground and to respond to people's concerns, especially on a subject that is a primary source of 'wicked' problems that pose real threats to peace and stability in Northern Ireland.

Beyond the deep-rooted conservatism in Northern Ireland's political culture, the reasons for this high degree of reluctance to provide broader means of democratic participation are by and large linked to the nature of the consociational arrangements. Deliberative democracy would maintain that all assumptions are open to challenge (Steiner, 2012, p. 7), and this sits uncomfortably with parties' claim that their constitutional aspirations, although diametrically opposed, remain resolutely intact in the consociational system. Although moderation is possible in this political scheme (Garry, 2009), consensus is not necessary, and a high-level sharing out of power has instead become the assumed substitute. As a result, pragmatism and bargaining are two finely honed skills in the Northern Ireland Executive, and they have worked relatively well in keeping all the main parties committed to political and peaceful means of governance, but they are inadequate for dealing with some of the region's 'wicked' problems. 


\section{Challenges faced by citizen-led deliberative initiatives}

Cause for hope, however, could lie in the sheer size of the public response to the CSI consultation, the strength and professionalism of the community and volunteer sector, and citizen-led initiatives to move political debate forward by generating new ideas. All these things point to a healthy potential for broadening civic participation in public debates on matters of shared social concern. The successful experiments with deliberative polling that occurred even during the Troubles have shown that there is a potential for consensus, even across political parties. More widespread have been the efforts at generating debate and communication, both verbal and digital, between people on matters of public concern through conventions, workshops, networks, blogs and discussion forums. These deliberation forums offer crosscommunity dialogue and provide opportunities for identifying common themes and needs across social divisions. It is nevertheless important not to place emphasis on the idea of these forums being able to come up with alternative or consensus-based solutions to social problems. Many of the public debates hosted by, for example, Platform for Change repeat, if not replicate, the positions set out by the parties and often defined by the conflict cleavage; 'agree to disagree' is a much more common outcome to such discussions than any common agreement. This is not to say that such discussions are fruitless, but it shows that communicating views and ideas on sensitive issues in a public forum and in an atmosphere of shared respect is an achievement in itself in this divided society.

It is worth considering the particular obstacles faced by these citizen-led deliberative efforts in Northern Ireland. First, there is a disproportionate reliance on just a few individuals. The key players behind contemporary deliberation initiatives were also the leaders of similar efforts 20 years ago, and their retirement may well leave gaping holes in the networks that are so critical to the successful organization of such forums, and also lead to a loss of motivation. ${ }^{26}$ Second, as discussed earlier, there is a remarkable lack of political support and interest. For example, all political parties in Northern Ireland participated in the New Ireland Group conventions up to the early 1990s, but since becoming established in the Assembly and Executive, none have taken any meaningful steps towards supporting deliberative polling or voting arrangements. Finally, and related to this point, in the absence of political validation, community groups tend to rely on their own political connections and the parties' wish to be seen to be acting in their singular constituency's interests to get local needs met. Thus, one community's requirements are posed against the 
other, and the pattern of separation that has become institutionalized at political level is replicated and reinforced at citizen level.

To sum up, the capacity inherent in deliberation to create a 'higher degree of collective knowledge and mutual moral responsibility' (Valadez, 2001, p. 32) is wasted under the consociational system of governance, which fails to recognize the positive, long-term potential of dialogue and consensus across community divides. Active civic leaders have no intention of allowing their deliberation initiatives and experiments to act as mere sops, in the absence of effective democracy in Northern Ireland.

If deliberative democracy is to take root, it has to be made clear that it does not foster argument for argument's sake, but rather that the outcomes of deliberation can be binding (Gutmann and Thompson, 2004, p. 5). In the absence of strong connections between citizen initiatives and real policy change, or even merely some indication of being 'heard' by those in power, the threat of political disaffection among the electorate is growing. If the capacity for institutional formalization and deliberative democracy is finally realized in Northern Ireland, the potential exists, through flexibility, sustained dialogue and imagination, to address some of the 'wicked' problems that bedevil its society. But if deliberation remains stagnant at the level of civilized discussion and pointless public consultation, people's demands for better democracy may gradually peter out into a reluctant acceptance of the institutionalized myth that Northern Ireland is a society of two irreconcilable halves.

\section{REFERENCES}

Agreement (1998). The Agreement reached in the Multiparty Negotiations, April 10, 1998. http://cain.ulst.ac.uk/events/peace/docs/agreement.pdf, date accessed July 1, 2013.

Balint, P.J., Stewart, R.E., Desai A. and Walters, L.C. (2011). Wicked Environmental Problems: Managing Uncertainty and Conflict. Washington, DC: Island Press.

BIC (2013). British-Irish Council website, www.britishirishcouncil.org/about, date accessed July $1,2013$.

Collier, P., Hoeffler, A. and Söderbom, M. (2008). 'Post-Conflict Risks', Journal of Peace Research, 45(4), 461-78.

De Benoist, A. (1985). Démocratie: le problème. Paris: Le Labyrinthe.

Dryzek, J. (2005). 'Deliberative Democracy in Divided Societies', Political Theory, 33, 218-41. 
Emerson, P.J. (1998). Preferendum Social Survey (2nd edition). Belfast: de Borda Institute.

—. (2010). 'Consensus Voting and Party Funding: A Web-Based Experiment', European Political Science, 9(1), 83-101.

Finley, M.I. (1973). Democracy Ancient and Modern. New Brunswick, NJ: Rutgers University Press.

Fishkin, J.S. (2009). When the People Speak: Deliberative Democracy and Public Consultation. Oxford: Oxford University Press.

Fishkin, J.S. and Luskin, R.C. (2005). 'Experimenting with a Deliberative Ideal: Deliberative Polling and Public Opinion', Acta Politica, 40, 284-98.

Fung, A. (2003). 'Recipes for Public Spheres: Eight Institutional Design Choices and Their Consequences', Journal of Political Philosophy, 11(3), 338-67.

Gaffikin, F. and Morrissey, M. (2011). Planning in Divided Cities. Oxford: Blackwell.

Garry, J. (2009). 'Consociationalism and Its Critics: Evidence from the Historic Northern Ireland Assembly Election 2007', Electoral Studies, 28(3), 458-66.

Government of the UK (2013). Building a Prosperous and United Community, HM Government and Northern Ireland Executive, June 14, 2013, www.gov.uk/government/uploads/system/uploads/attachment_data/file/206979/Building _a_Prosperous_and_United_Community.pdfhttps://www.gov.uk/government/uploads/sys tem/uploads/attachment data/file/206979/Building_a Prosperous and United Communi ty.pdf, date accessed July 1, 2013.

Gutmann, A. and Thompson, D. (2004). Why Deliberative Democracy? Princeton, NJ: Princeton University Press.

Harvey, C. (2000). 'Governing after the Rights Revolution', Journal of Law and Society, 27(1), 61-97.

Hayes, B.C. and McAllister, I. (2013). 'Gender and Consociational Power-Sharing in Northern Ireland', International Political Science Review, 34(2), 123-39.

Horowitz, D.L. (1993). 'Democracy in Divided Societies', Journal of Democracy, 4(4), 18-38.

Janeczko, L.S. (2011). Managing Wicked Policy Problems: A Case for Deliberative Practices, Thesis submitted for the degree of BA (Hons.), Murdoch University, 
http://researchrepository.murdoch.edu.au/6404/2/02Whole.pdf, date accessed July 1, 2013.

Lijphart, A. (1969). 'Consociational Democracy', World Politics, 21(2), 207-25.

Lipset, S.M. (1960). Political Man: The Social Bases of Politics. Garden City, NY: Doubleday.

Little, A. (2008). Democratic Piety: Complexity, Conflict and Violence. Edinburgh: Edinburgh University Press.

Luskin, R.C., O’Flynn, I., Fishkin, J.S and Russell, D. (forthcoming, published online December 2012). 'Deliberating across Deep Divides', Political Studies, [tbc].

McDevitt, C. (2013). Motion proposed by SDLP MLA, 'Civic Forum on Participative Democracy', NI Assembly Debate, April 9, 2013,www.niassembly.gov.uk/AssemblyBusiness/Official-Report/Reports-12-13/9-April-2013/\#7, date accessed July 1, 2013.

Miller, D. (1993). 'Deliberative Democracy and Social Choice', in D. Held (ed.), Prospects for Democracy: North, South, East, West (pp. 74-92). Cambridge: Polity Press.

—. (2003). 'Deliberative Democracy and Social Choice', in J.S. Fishkin and P. Laslett (eds.), Debating Deliberative Democracy (pp. 182-99). Oxford: Blackwell.

Morrice, J. (2001). Contribution by NI Women's Coalition MLA, NI Assembly Debate on the Civic Forum, February 6, 2001, http://archive.niassembly.gov.uk/record/reports/010206c.htm, date accessed July 1, 2013.

Morris-Jones, W.H. (1954). 'In Defence of Apathy: Some Doubts on the Duty to Vote', Political Studies, 2(1), 25-37.

Muttarak, R., Hamill, H., Heath, A. and McCrudden, C. (2013). 'Does Affirmative Action Work? Evidence from the Operation of Fair Employment Legislation in Northern Ireland', Sociology, 47(3), 560-79.

Mutz, D.C. (2006). Hearing the Other Side: Deliberative versus Participatory Democracy. Cambridge: Cambridge University Press.

NIA (2010). Voting and Community Designation, Research and Library Service Briefing Note 102/10, NIAR 353-10, September 28, 2010, www.niassembly.gov.uk/researchandlibrary/2010/10210.pdf, date accessed July 1, 2013.

NILT (2010). Northern Ireland Life and Times Survey 2010, www.ark.ac.uk/nilt/2010, date accessed July 1, 2013. 
-. (2012). Northern Ireland Life and Times Survey 2012, www.ark.ac.uk/nilt/2012/Political_Attitudes/IRBRIT.html, date accessed July 1, 2013.

NISRA (2011). Results of the 2011 Census of Northern Ireland. Belfast: Northern Ireland Statistics and Research Agency. www.nisra.gov.uk/Census/2011_results.html, date accessed July 1, 2013.

Nolan, P. (2013). Northern Ireland Peace Monitoring Report, no. 2. Belfast: Joseph Rowntree Foundation/Community Relations Council. www.community-relations.org.uk/peacemonitor, date accessed July 1, 2013.

NSMC (2002). NSMC Plenary Joint Communiqué, June 28, 2002, www.northsouthministerialcouncil.org/index/publications/joint-communiques/plenaryjc/plenary jc 28 june 2002.htm, date accessed July 1, 2013.

-. (2011). NSMC Plenary Joint Communiqué, June 10, 2011, www.northsouthministerialcouncil.org/index/publications/joint-communiques/plenaryjc/plenary_jc_10_june_2011.htm, date accessed July 1, 2013.

-. (2012). NSMC Plenary Joint Communiqué, November 2, 2012, www.northsouthministerialcouncil.org/index/publications/joint-communiques/plenaryjc/plenary joint communique 02 november 2012.htm, date accessed July 1, 2013.

—. (2013). NSMC Plenary Joint Communiqué, July 5, 2013, http://www.northsouthministerialcouncil.org/index/publications/jointcommuniques/plenary-jc/plenary_joint_communique_05_july_2013.htm, date accessed July 15, 2013.

O’Flynn, I. (2006). Deliberative Democracy and Divided Societies. Edinburgh: Edinburgh University Press.

—. (2007). 'Review Article: Divided Societies and Deliberative Democracy', British Journal of Political Science, 37, 731-51.

OFMDFM (2010). Responses to the consultation on Cohesion, Sharing and Integration draft programme, November 2010, www.ofmdfmni.gov.uk/csi-consultation-responses, date accessed July 1, 2013.

-. (2011). Programme for Cohesion, Sharing and Integration Consultation Analysis. Belfast: Wallace Consulting, www.ofmdfmni.gov.uk/final_web_version_-_csi_analysis_report__pdf_1.12_mb_.pdf, date accessed July 1, 2013. 
—. (2013). Together: Building a United Community, www.ofmdfmni.gov.uk/together_building_a_united_community.pdf, date accessed July $1,2013$.

Padley, M. and Hirsch, D. (2013). Child Poverty Map of the UK. London: Campaign to End Child Poverty, February 2013, www.endchildpoverty.org.uk/images/ecp/130212\%20ECP\%20local\%20report\%20final(1 L.pdf, date accessed July 1, 2013.

Pollak, A. (1993a). A Citizens' Inquiry: The Opsahl Report on Northern Ireland. Dublin: Lilliput Press for Initiative '92.

-. (1993b). 'An Experiment in Communication', Index on Censorship, 22(8), 16.

Porter, E. (2000a). 'Participatory Democracy and the Challenge of Dialogue across Difference', in C. Roulston and C. Davies (eds.), Gender, Democracy and Inclusion in Northern Ireland (pp. 141-63). Basingstoke: Palgrave.

-. (2000b). 'Risks and Responsibilities: Creating Dialogical Spaces in Northern Ireland', International Feminist Journal of Politics, 2(2), 163-84.

Rittel, H.W. J. and Webber, M.M. (1973). 'Dilemmas in a General Theory of Planning', Policy Sciences, 4, 155-69.

Robb, J. (1991). 'Preface', in P. J. Emerson (ed.), The Other Talks on the Constitutional Question: Conference Report. Belfast: New Ireland Group, October 26, 1991.

Ruane, J. and Todd, J. (2010). From 'A Shared Future' to 'Cohesion, Sharing and Integration': An Analysis of Northern Ireland's Policy Framework. A report for the Joseph Rowntree Charitable Trust, http://www.jrct.org.uk/core/documents/download.asp?id=447, date accessed July 1, 2013.

Sisk, T.D. (1996). Power Sharing and International Mediation in Ethnic Conflicts. Washington, DC: United States Institute of Peace.

Steiner, J. (2012). The Foundations of Deliberative Democracy. Cambridge: Cambridge University Press.

Taylor, R. (Ed.) (2009). Consociational Theory: McGarry and O Leary and the Northern Ireland Conflict. Abingdon: Routledge. 
Trimble, D. (2001). Contribution by the First Minister, NI Assembly debate on the Civic Forum, February 6, 2001, http://archive.niassembly.gov.uk/record/reports/010206.htm\#3, date accessed July 1, 2013.

Valadez, J.M. (2001). Deliberative Democracy, Political Legitimacy and Self-Determination in Multicultural Societies. Boulder, CO: Westview Press.

Wilson, R. (1995). 'Introduction', 'New Thinking for New Times', Democratic Dialogue report no. 1. Belfast: Democratic Dialogue.

Zürcher, C. (2011). 'Building Democracy While Building Peace', Journal of Democracy, 22(1), $81-95$.

\section{NOTES}

1. The use of consociationalism in Northern Ireland is a matter of heated scholarly debate (for a summary, see Taylor, 2009).

2. The St. Andrews Agreement (2006) ended the political stalemate and enabled devolution to be restored (direct rule from Westminster was imposed from October 2002 to May 2007) by bringing the by-then largest party, the hardline Democratic Unionist Party (DUP), into the power-sharing executive.

3. In viewing apathy as increasing the risk of extremism, this analysis sides with de Benoist (1985) <AQ: Is the year 1985 as in the reference list? > and Finley (1973) against Morris-Jones (1954) and Lipset (1960), who saw apathy <AQ: Is this correct?> acting as a guard against it.

4. The street violence resulting from the political row over lowering the Union Flag over Belfast's City Hall in the winter of 2012/13 and the riots arising from disputes about Orange Parades through nationalist areas that have taken place on an almost annual basis since the mid1990s are two prime examples (see Nolan, 2013).

5. The graph shows the percentage of Protestant respondents describing their national identity as 'British' and those describing it as 'Irish', and the same for Catholic respondents. Other options included 'other' and 'Ulster'. Sources: Loyalty Survey 1968 (http://discover.ukdataservice.ac.uk/catalogue/?sn=1040\&type=Data\%20catalogue);

Northern Ireland Attitudes Survey 1978 (http://discover.ukdataservice.ac.uk/catalogue?sn=1347) ; Northern Ireland Social Attitudes Survey 1989 and 1995 (www.esds.ac.uk/findingData/nisasTitles.asp); Northern Ireland Life 
and Times Survey 1999 (www.ark.ac.uk/nilt/1999/Community Relations/NINATID.html);

Northern Ireland Assembly Elections Survey 2003

(http://discover.ukdataservice.ac.uk/catalogue/?sn=5394\&type=Data\%20catalogue);

Northern Ireland Life and Times Survey 2003, 2006, 2008, 2009, 2010, 2012

(www.ark.ac.uk/nilt/results/searchyear.html), all accessed 1 July 2013.

6. The 2010 Northern Ireland Life and Times (NILT) Survey is used here because the 2012 NILT survey changed questions on identity so that responses could be more nuanced: in other words, respondents could answer that they were one not the other, or more one than the other, or equally British and Irish. This obviously affected the results of this survey and negated any comparison with previous surveys.

7. Other forms of 'alternative' options to this binary conception of political identity and preference in Northern Ireland include the 29 percent who describe themselves as having a Northern Irish identity and the approximately 17 percent who claim no religious identity (NILT, 2010; NISRA, 2011).

8. This is especially true of the younger generation, with 66 percent of 18- to 24-year-old respondents describing themselves as 'neither' unionist nor nationalist (NILT, 2010).

9. Agreement (1998) Constitutional Issues, Art. 1(v).

10. The NIWC was established in 1996 to raise the profile and presence of women in Northern Ireland politics, beginning with the forum for multiparty talks. The party's decision to redesignate itself from 'other' to 'unionist' in 2001, in order to help the Assembly gain the necessary cross-community qualified majority vote and avoid another suspension of devolution, demonstrated the invidious position that non-aligned parties are faced with in the consociational system. Moreover, it turned out to be an act of martyrdom with short-lived effect. Devolution was suspended again in 2002, and the party rapidly lost electoral support. It was dissolved in 2006, by which time it had lost both its seats in the Assembly and all its seats on local councils.

11. Garry (2009) argues that consociationalism has increased moderation in Northern Ireland and that institutional incentives for extreme parties to 'moderate' have already taken place in unionism. His study focuses on electorate attitudes, which means that it actually confirms the analysis here that the electorate itself generally has moderate opinions. But wider evidence from policy-making (e.g., only six legislative bills were enacted by the NIA between July 2011 
and December 2012 [Nolan, 2013, p. 148]), ground-level political activity and political discourse in the public sphere would suggest that the consociational system is still a long way from enabling parties to find common ground between the blocs. Indeed, Garry's (2009) analysis may actually be seen to confirm that the predominance of the conflict cleavage in the Assembly is very much out of sync with the electorate it represents.

12. According to the 2011 census, over one-third of households are in electoral wards where more than 80 percent of residents are from the same religious community (Nolan, 2013, p. 120).

13. The Green Party and the Alliance Party are the most important parties with the 'other' designation in the Assembly. Following the 2011 Assembly election, the Green Party holds one seat and the Alliance holds eight. Having had a fairly stable portion of the vote (around 4 percent) for over a decade, the Alliance made significant gains in 2010, including the election of an MP to Westminster. But this success was due in large part to localized political activity, with some Protestant community groups attempting to regain DUP support by (temporarily) switching their support to the Alliance: a cynical effort which demonstrates, if demonstration were needed, the dangers of political parties relying on being seen to meet the needs of single community constituencies.

14. The turnout for the 2011 Assembly election was 54.5 percent, down from 62.9 percent in the 2007 election.

15. Given the nature and remit of these various meetings, the NSMC is interdependent with the Northern Ireland Executive. It was thus inactive during the periods when the Assembly was suspended due to political stalemate (the longest period being 2002-2007).

16. There is clearly more support from the Republic of Ireland for this initiative. A review of the terms of the Forum was conducted by the Irish government and submitted to the Northern Ireland Executive in 2008; in 2009 and 2010, the Irish government facilitated consultative conferences with social partners and civil society groups across the island but, without the agreement of the Northern Ireland Executive, these events could not be described as constituting a conference of the North South Consultative Forum.

17. The motion put to the Assembly was: 'To fulfill the commitments of the Belfast Agreement to participative democracy and to facilitate an all-inclusive consultative forum to help address the social, economic and cultural issues facing this region' (McDevitt, 2013). 
18. Author's first interview with Peter J. Emerson, director of the de Borda Institute, Belfast, May 14, 2013.

19. Author's follow-up interview with Peter J. Emerson, Belfast, 27 June 2013.

20. For example, the DUP refused to attend if Sinn Féin were present, and so Emerson specifically requested that Sinn Féin absent themselves from the third convention so that a DUP representative could engage in the process.

21. Information presented here on the structures and procedures of the New Ireland Group conventions was gathered from a range of contemporary reports on these events shared with the author by P. J. Emerson.

22. This is similar to the finding of the 1998 'preferendum' experiment discussed earlier. But in both cases, it is worth considering the possible effects of the self-exclusion of the hardline DUP unionist party from the deliberation process leading to this conclusion.

23. See www.platformforchange.net, date accessed 1 July 2013.

24. 'Slugger O'Toole' (http://sluggerotoole.com/) is the most established independent website for 'conversations about politics' in Northern Ireland. It also acts as a channel for increasing participation in local forums, and occasionally organizes events of its own. '15 Years On' (http://15yearson.com/), established in 2012 as a blog about the progress of peace since the 1998 Agreement, has expanded to help facilitate more traditional forums for engagement, such as a workshop on the 'next generation'.

25. Publication of this strategy was timed to enable an announcement to be made by the British government of major investment in capital funding and 'frontline projects' for 'tackling division' (Government, 2013). This announcement came but a few days before world leaders arrived in Northern Ireland for the British government's hosting of the G8 summit in Co. Fermanagh (June 2013), and a few weeks after the secretary of state for Northern Ireland had mooted the possibility of withholding a promised economic package for Northern Ireland in the absence of developments in the Executive's community relations policy (Belfast Telegraph, April 13, 2013). 